\title{
Viral Oncogene Protein
}

National Cancer Institute

\section{Source}

National Cancer Institute. Viral Oncogene Protein. NCI Thesaurus. Code C16935.

Viral proteins that have the potential to cause transformation of the infected cell and

may result in carcinogenesis. 